\title{
Sestonic bacterial nutrient limitation in a northern temperate river and the impact of pulp-mill effluents
}

\author{
Mohamed N. Mohamed ${ }^{1,2, *}$, Richard D. Robarts ${ }^{1}$ \\ ${ }^{1}$ National Water Research Institute, Saskatoon, Saskatchewan S7N 3H5, Canada \\ ${ }^{2}$ Present address: Dept. of Biology, University of Waterloo, 200 University Ave. W., Waterloo, Ontario N2L 3G1, Canada
}

\begin{abstract}
Bacterial growth limitation and the effect of pulp-mill effluents (PME) on sestonic bacteria were studied in a northern temperate river (the Fraser River, British Columbia, Canada). Nutrient addition experiments demonstrated that sestonic bacterial growth was potentially limited by P. Experiments were done by adding $\mathrm{N}$, $\mathrm{P}$, or organic carbon to 21 microcosms of river water. The addition of $\mathrm{P}$ (singly, and in combination with $\mathrm{N}$ and $\mathrm{C}$ ) increased bacterial production (rate of ${ }^{3} \mathrm{H}$-thymidine incorporation) and activity $\left({ }^{14} \mathrm{C}\right.$-glucose uptake), while the addition of $\mathrm{N}$ or organic carbon did not. The inflow of PME into the Fraser River increased bacterial abundance, activity, and production in 2 ways. First, P in the PME increased native bacterial abundance and processes, and second, PME provided a source of active bacteria to the river.
\end{abstract}

KEY WORDS: Bacteria $\cdot$ River $\cdot$ Phosphorus $\cdot$ Limitation $\cdot$ Pulp mill $\cdot$ Nutrient $\cdot$ Effluent $\cdot$ Sewage Resale or republication not permitted without written consent of the publisher

\section{INTRODUCTION}

Heterotrophic bacteria are important for nutrient cycling, decomposition, and possibly for secondary production in aquatic systems. While much of the current interest in the significance of bacterial secondary production has focused on lentic or marine systems, it may play an even more important role in the secondary production of lotic environments. Allochthonous inputs of organic $\mathrm{C}$ and bacteria are more important in flowing waters than in other systems. Additionally, the main consumers of bacteria in lotic systems are meiofaunal filter feeders and biofilm grazers: their assimilation of bacterial carbon is 1 to 4 orders of magnitude higher than other bacterial consumers (Meyer 1994). As a result, the flow of carbon from bacteria to large consumers can occur in a single trophic transfer in lotic systems (Meyer 1994). Bacteria in riverine seston may have dislodged from surfaces in the river, or be of allochthonous origin. The metabolism of these bacteria is often quite low, probably because many are terrestrial or biofilm bacteria that are unable to remain active in the seston (Wainwright et al. 1992). While largely metabolically inactive, these bacteria may still be an important food source for filterfeeding organisms.

The limitation of bacterial production in aquatic systems has been an essential issue for microbial ecologists for some time (Azam et al. 1994). Growth limitation of bacteria by organic $\mathrm{C}$, or by inorganic nutrients, has been found in a variety of aquatic environments (e.g. Rivkin \& Anderson 1997, Zweifel 1999, Church et al. 2000, Kisand et al. 2001). Riverine studies have also found bacterial growth to be limited by organic $\mathrm{C}$ in some environments and at some times, and by inorganic nutrients at others (Benner et al. 1995, Arthurs 1998, Foreman et al. 1998, Mohamed et al. 1998).

The impact of pulp-mill effluents (PME) on rivers has undergone extensive investigation for several years, focussing primarily on the effects of increased biochemical oxygen demand (BOD) and toxicity to aquatic biota. Biological oxidation systems have been installed to address the problem of BOD for aquatic biota, while chlorine dioxide substitution for bleaching has largely addressed the concern of PME toxicity in rivers (Gibbons et al. 1992). Still, some toxic chlorinated organic compounds and several natural toxic compounds such as resin and fatty acids will be 
Table 1. Water chemistry data of Fraser River water upstream of effluent input (river water) and undiluted pulp-mill effluent (PME) (data from J. Culp \& K. J. Cash, National Water Research Institute, unpubl. data). Data encompass dates of fall 1994 experiments. $\mathrm{TKN}=$ total Kjeldahl nitrogen, $\mathrm{SRP}=$ soluble reactive phosphorus, $\mathrm{TDP}=$ total dissolved phosphorus, $\mathrm{TP}=$ total phosphorus, $\mathrm{DOC}=$ dissolved organic carbon

\begin{tabular}{|c|c|c|c|c|c|c|c|c|c|}
\hline & $\begin{array}{l}\mathrm{NO}_{3}-\mathrm{N} \\
\left(\mu \mathrm{gl}^{-1}\right)\end{array}$ & $\begin{array}{l}\mathrm{NH}_{4}-\mathrm{N} \\
\left(\mu \mathrm{g} \mathrm{l}^{-1}\right)\end{array}$ & $\begin{array}{c}\text { TKN } \\
\left(\mu \mathrm{g} \mathrm{l}^{-1}\right)\end{array}$ & $\begin{array}{r}\text { SRP-P } \\
\left(\mu g l^{-1}\right)\end{array}$ & $\begin{array}{c}\text { TDP } \\
\left(\mu \mathrm{g} \mathrm{l}^{-1}\right)\end{array}$ & $\begin{array}{c}\text { TP } \\
\left(\mu \mathrm{g} \mathrm{l}^{-1}\right)\end{array}$ & $\mathrm{pH}$ & $\begin{array}{c}\text { Alkalinity } \\
\left(\mathrm{mg} \mathrm{l}^{-1} \text { as }\right. \\
\left.\mathrm{CaCO}_{3}\right)\end{array}$ & $\begin{array}{c}\text { DOC } \\
\left(\mathrm{mg} \mathrm{l}^{-1}\right)\end{array}$ \\
\hline \multicolumn{10}{|c|}{ River water } \\
\hline Mean & 57.2 & 52.3 & 265 & 3.5 & 6.9 & 61.9 & 7.63 & 67.7 & 1.5 \\
\hline Range & $38.1-93.3$ & $5.7-114$ & $73.5-462$ & $0.5-11$ & $2.3-14$ & $16.6-158$ & $7.56-7.70$ & $61.0-78.8$ & $0.96-2.6$ \\
\hline \multicolumn{10}{|l|}{ PME } \\
\hline Mean & 27.4 & 754.6 & 2973 & 496.3 & 1045.3 & 1613.9 & 7.39 & 302.7 & 127.7 \\
\hline Range & $14.8-39.9$ & $20.7-3800$ & $1903-4131$ & $120.4-882.0$ & $381.4-3667$ & $744.0-4859$ & $7.02-8.00$ & $264.4-348.0$ & $114.6-155.9$ \\
\hline
\end{tabular}

released even if chlorine is entirely excluded from the bleaching process (McLeay 1987).

With the reduction of BOD and toxicity, the nutrients and organic matter that are discharged by pulp mills remain a concern, since bacteria are sensitive to very small changes in the concentration of dissolved organic carbon (DOC) and inorganic nutrients. Increased bacterial growth may result in changes to both direct and indirect consumers of bacteria in the river. Changes in bacterial activity may also change rates of decomposition and nutrient mineralisation in a system, thus changing the availability of nutrients to the system and the growth of autotrophic organisms, such as algae (Paul et al. 1991). We used nutrient enrichment assays to assess nutrient limitation of, and the effect of PME on, sestonic bacterial abundance, production, and activity in the Fraser River, a northern temperate river, in British Columbia, Canada.

\section{MATERIALS AND METHODS}

Study site. Experiments were conducted at the Fraser River near the city of Prince George, British Columbia (535 $\left.58^{\prime} 45^{\prime \prime} \mathrm{N}, 122^{\circ} 41^{\prime} 30^{\prime \prime} \mathrm{W}\right)$, Canada, just upstream of Northwood Pulp and Timber, which is the first anthropogenic point source input into the river. From its source to a monitoring site (Shelly station) approximately $4 \mathrm{~km}$ upstream of the sampling site, the Fraser River drains an area of $32400 \mathrm{~km}^{2}$ (Anonymous 1991). Riverine discharge at Shelly station is high and variable, ranging from $97 \mathrm{~m}^{3} \mathrm{~s}^{-1}$ (lowest yearly mean monthly discharge) to $3470 \mathrm{~m}^{3} \mathrm{~s}^{-1}$ (highest yearly mean monthly discharge) (Swain et al. 1994). Nutrient and DOC concentrations in the mill's PME were much higher than in the river water upstream of the effluent input (Table 1).

Sample collection. Work was done at the National Water Research Institute's mesocosm facility located on the bank of the Fraser River at Northwood Pulp and Timber. A complete description of this facility is given in Culp et al. (1996). Briefly, the experimental facility consisted of fifteen 200 l, $38 \mathrm{~cm}$ deep, circular flowthrough containers. River water was pumped into these containers from an intake that was upstream of the effluent discharge point. The intake was $0.5 \mathrm{~m}$ above the river bottom and at least $3 \mathrm{~m}$ from the river's shore (which varied with river discharge). Delivery rate to the containers was $21 \mathrm{~min}^{-1}$, resulting in a mean residence time of $2 \mathrm{~h}$ and a mean mid-water speed of $20 \pm 3 \mathrm{~cm} \mathrm{~s}^{-1}$. Tanks were either amended with 1 or $3 \% \mathrm{v} / \mathrm{v}$ PME obtained from the mill, or left unamended to serve as controls. These effluent concentrations were chosen because they were the minimum and maximum concentrations of PME that typically occurred just downstream of the mill.

Experimental protocols. Samples for enumeration of bacteria were preserved with acid Lugol's iodine $(2 \% \mathrm{v} / \mathrm{v})$, decolourised with sodium thiosulphate, stained with 4',6-diamidino-2-phenylindole (DAPI) and enumerated by direct epifluorescence microscopy (Velji \& Albright 1993). A minimum of 300 bacteria per slide were counted under 1000× magnification.

Bacterial production was measured by the rate of incorporation of $\left[\right.$ methyl- $\left.{ }^{3} \mathrm{H}\right]$ thymidine (TdR) into DNA. TdR incorporation experiments were conducted as follows: triplicate $5 \mathrm{ml}$ aliquots of sample water were placed in autoclaved $10 \mathrm{ml}$ culture tubes. TdR at a final concentration of $45 \mathrm{nM}$ was added, and samples were incubated for $120 \mathrm{~min}$. Concentration and incubation times were determined from the initial saturating concentration and time-course incorporation experiments (Robarts \& Zohary 1993). Killed controls for each treatment were prepared by adding $5 \%$ formalin (final conc.) to one set of samples before the addition of TdR. Incubations were terminated with the addition of $5 \%$ formalin. Bacterial DNA was extracted from the samples by the method of Robarts \& Wicks (1989). 
Briefly, $250 \mu \mathrm{l}$ of $5 \mathrm{~N} \mathrm{NaOH}$ was added to each sample. After $15 \mathrm{~min}, 1 \mathrm{ml}$ of ice-cold $100 \% \mathrm{w} / \mathrm{v}$ trichloroacetic acid (TCA) was added. Samples were then placed on ice for $15 \mathrm{~min}$ before filtering through $0.22 \mu \mathrm{m}$ pore-size cellulose nitrate filters. Filters were rinsed with $3 \times 3 \mathrm{ml}$ each of ice-cold $5 \%$ w/v TCA, $50 \%$ w/v phenol-chloroform, and $80 \%$ v/v ethanol. They were then dissolved in ethyl acetate before the addition of scintillation cocktail. Radioactivity was measured using a liquid scintillation counter (Canberra Packard) with an external standard for quench correction.

Bacterial metabolic activity in the treatments was determined from the uptake of a single added concentration of $\left[{ }^{14} \mathrm{C}\right]$ glucose (Wright \& Coffin 1984). This method was used in conjunction with the TdR method because during unbalanced growth, bacterial activity may not vary concomitantly with bacterial division rate. Also, because of the differing metabolic capabilities of members of mixed bacterial assemblages, 2 substrates can cross-verify results. Initial experiments were done to determine the concentration of glucose required to saturate bacterial uptake. Uniformly labelled $\left[{ }^{14} \mathrm{C}\right]$ glucose was added at $180 \mathrm{nM}$ and incubated for $180 \mathrm{~min}$, then terminated with the addition of $5 \%$ formalin (final conc.). Killed controls for each treatment were prepared by adding $5 \%$ formalin (final conc.) to one set of samples before the addition of $\left[{ }^{14} \mathrm{C}\right]$ glucose. Samples were filtered through $0.22 \mu \mathrm{m}$ pore-size cellulose nitrate filters and rinsed with $3 \times 5 \mathrm{ml}$ of $0.45 \mu \mathrm{m}$ filtered river water to remove unincorporated $\left[{ }^{14} \mathrm{C}\right]$ glucose. Filters were counted as described above.

Mesocosm experiments. Water samples were collected from mesocosms on 7 dates in September and October 1994 during the time of year when the total P concentration is typically the lowest in the river before ice cover (Environment Canada unpubl. data). Three replicate samples were collected from each treatment containing 0,1 , and $3 \% \mathrm{v} / \mathrm{v}$ PME. These were subsampled for determination of bacterial abundance, production, and metabolic activity.

Microcosm experiments. Nutrient addition experiments were conducted to determine the nutrient responsible for limiting sestonic bacterial production in the Fraser River and the effect of PME on sestonic bacteria. These experiments were done using 21 cultures of river water, to which varying nutrient and PME additions were made.

In all experiments in which nutrient and organic $\mathrm{C}$ amendments were made, the following concentrations were used: $200 \mu \mathrm{g} \mathrm{C} \mathrm{l}^{-1}$ of mixed amino acids (glycine, serine, glutamine, methionine, valine) for organic carbon additions, $1100 \mu \mathrm{g} \mathrm{N}^{-1}$ as $\mathrm{NaNO}_{3}$ for $\mathrm{N}$ additions, and $160 \mu \mathrm{g} \mathrm{P} \mathrm{l}^{-1}$ as $\mathrm{KH}_{2} \mathrm{PO}_{4}$ for $\mathrm{P}$ additions. Cultures in the nutrient addition experiments were mixed and aerated with $0.2 \mu \mathrm{m}$ filtered air.

Nutrient addition experiments. Autumn experiment: An experiment was done to determine whether $\mathrm{N}$ or $\mathrm{P}$ was the limiting nutrient for river bacteria at a time when $\mathrm{P}$ was at its approximately lowest concentration during the year. Three replicates of 4 treatments were used; unamended river water (rw), river water plus $N(N)$, river water plus $P(P)$, and river water plus $\mathrm{N}$ and $\mathrm{P}(\mathrm{NP})$. Treatment flasks were sampled for bacterial abundance, production, and activity at the beginning of the experiment and at $96 \mathrm{~h}$.

Spring experiment: An experiment was done to determine whether bacteria were limited by organic $\mathrm{C}$ or inorganic nutrients at the approximate time of highest annual $\mathrm{P}$ concentrations in the river. It consisted of 3 replicate treatments of unamended river water (rw), river water plus DOC $(\mathrm{C})$, river water plus $\mathrm{N}(\mathrm{N})$, river water plus $\mathrm{P}(\mathrm{P})$, river water plus $\mathrm{N}$ and $\mathrm{P}(\mathrm{NP})$, and river water plus DOC, N, and P (CNP). Bacterial abundance, activity and production were determined as described above.

PME addition experiments. PME-nutrient interaction experiments: These experiments were conducted in both autumn and spring. They were similar to the nutrient addition experiments done with river water, except that nutrient additions were made to river water to which $3 \%$ PME was also added. Treatments were: unamended river water (rw), $3 \% \mathrm{PME}$ in river water (PME), 3\% PME plus DOC $(\mathrm{PME}+\mathrm{C})$, $3 \%$ PME plus $\mathrm{N}$ and $\mathrm{P}$ (PME+NP), and $3 \% \mathrm{PME}$ plus DOC, N, and P (PME+CNP). They were done to assess whether the PME (at $3 \%$ ) caused a shift in nutrient limitation of bacteria. Bacterial abundance, production, and activity were measured over a course of approximately $7 \mathrm{~d}$.

PME activity experiment: In autumn, bacterial abundance and activity were measured in the raw effluent to determine whether the effluent was a source of active bacteria to the river. Since we only wanted an indication of how active the bacteria in the effluent were, and bacterial cell production in the effluent pond was not of interest to us, we measured only bacterial activity in the undiluted PME. Activity measurements were made at the temperature of the effluent pond (ca. $21^{\circ} \mathrm{C}$ ) and at river temperature (ca. $5^{\circ} \mathrm{C}$ ). Three replicate effluent and river water samples were collected as described above. One set of bottles containing effluent was held at the temperature in the effluent pond, while another set of bottles was cooled and held at river temperature by immersion into river water. After the effluent samples had cooled to river water temperature (ca. $20 \mathrm{~min}$ ), aliquots were removed from the bottles containing effluent (warm and cooled) and the unamended river water. Glucose uptake and 
bacterial abundance were measured as described previously.

Sterile effluent experiment. An experiment was conducted in an attempt to separate the effects of a bacterial input by the effluent from possible nutrient stimulation effects of the effluent. This was done by filter-sterilising effluent, then adding it to the river water at a dilution of $3 \%$. Effluent was filter sterilised by sequential filtration through a Whatman \#41 paper filter, a Whatman GF/F filter, a $0.45 \mu \mathrm{m}$ pore-size filter, and finally through a $0.22 \mu \mathrm{m}$ pore-size filter.

Treatments for this experiment were 3 replicates each of unamended river water (rw), $3 \%$ sterile effluent (PMEF), and $3 \%$ filter-sterilised effluent plus DOC $(\mathrm{PMEF}+\mathrm{C}), 3 \%$ sterile effluent plus $\mathrm{N}$ and $\mathrm{P}(\mathrm{PMEF}+$ $\mathrm{NP}$ ), and $3 \%$ sterile effluent plus DOC, $\mathrm{N}$, and $\mathrm{P}$ (PMEF+CNP). Bacterial abundance, production, and activity were measured for $7 \mathrm{~d}$ as described above.

Statistical analyses of data. The hypothesis that the addition of nutrients or PME did not cause a change in bacterial abundance, production, or activity was tested using a 1-way ANOVA at the time points of greatest separation among treatments for each parameter measured in each experiment. Examination of data for normality and homogeneity of variance indicated that TdR incorporation and glucose uptake data required application of a log transformation prior to the ANOVA. Pairwise comparisons following a significant ANOVA were conducted using a Fisher's Least Significant Difference (LSD) test. A significant response was considered to be at $\alpha<0.05$. Unless otherwise noted, specific values for TdR incorporation and glucose uptake (rates normalized to cell numbers) are reported.

\section{RESULTS}

\section{Mesocosm experiments}

Bacterial abundances were not significantly different on September $25(p=0.278)$ or October $17(p=0.104)$, but were on October $2(p=0.038)$ and $12(p=0.010)$, with $3 \%$ PME significantly higher in bacterial abundance than unamended river water or $1 \%$ PME (Fig. 1). TdR incorporation was significantly higher in $3 \%$ PME than in $1 \% \mathrm{PME}$, and higher in $1 \% \mathrm{PME}$ than unamended river water on all dates ( $p<0.001$ on all dates). Glucose uptake rate followed the same pattern as TdR incorporation, with treatment differences on September 25, October 2, and October 17 ( $p<0.001$ on each date) but not on October $2(p=0.160)$. The magnitude of treatment differences was quite large, with mean TdR incorporation rate in $3 \%$ PME ca. 3 times higher than in $1 \%$ PME, and ca. 30 times higher than in unamended river water.

\section{Nutrient addition experiments}

\author{
Autumn experiment
}

The addition of $\mathrm{N}$ alone did not result in TdR incorporation $(p=0.447)$ or glucose uptake $(p=0.181)$ over that of the unamended river water (Fig. 2a). While N alone did not increase bacterial abundance either, the effect was marginal ( $p=0.073)$. Addition of $P$ resulted in an increase in bacterial abundance $(p=0.005)$ and glucose uptake $(p=0.046)$ over the levels in unamended river water and the $\mathrm{N}$-added treatment, but not an increase in TdR incorporation $(p=0.431)$. Addition of $\mathrm{N}$ and $\mathrm{P}$ together, however, did result in an increase in TdR incorporation $(p=0.015)$.

\section{Spring experiment}

The addition of either $\mathrm{C}$ or $\mathrm{N}$ did not result in a change in bacterial abundance $(\mathrm{C}$ added, $\mathrm{p}=0.501$; $\mathrm{N}$ added, $\mathrm{p}=0.153)$, TdR incorporation ( $\mathrm{C}$ added, $\mathrm{p}=0.491 ; \mathrm{N}$ added, $\mathrm{p}=0.499)$, or glucose uptake ( $\mathrm{C}$ added, $\mathrm{p}=0.426 ; \mathrm{N}$ added, $\mathrm{p}=0.546$ ) compared to the unamended river water. However, the addition of $\mathrm{P}$ alone resulted in an increase in all measures compared to the unamended water as well as the $\mathrm{C}$ or $\mathrm{N}$ treatments ( $p<0.001$ for all measures; Fig. 2b). Addition of $\mathrm{N}$ and $\mathrm{P}$ together did not result in a further change in any of the above parameters compared to the treatment in which only $\mathrm{P}$ was added (bacterial abundance, $\mathrm{p}=0.690 ; \mathrm{TdR}$ incorporation, $\mathrm{p}=0.883 ;$ glucose uptake, $p=0.652$ ). Addition of $\mathrm{C}, \mathrm{N}$, and $\mathrm{P}$ together resulted in a further increase in bacterial abundance $(p=0.006)$ and glucose uptake $(p=0.038)$, but not TdR incorporation ( $p=0.669$ ) compared to the addition of $\mathrm{N}$ and $\mathrm{P}$ together.

\section{PME addition experiments}

PME-nutrient interaction

In the autumn experiment, all PME-added treatments showed increased bacterial abundance $(p=0.007)$, TdR incorporation $(p=0.022)$, and glucose uptake ( $p=0.002$ ) compared to that of the unamended river water (Fig. 2c). PME+C did not result in a further increase in any of the measures over the levels of PME alone (bacterial abundance, $\mathrm{p}=0.341$; TdR incorporation, $\mathrm{p}=0.718$; glucose uptake, $\mathrm{p}=0.938$ ). In contrast, PME+NP resulted in a significant increase in bacterial abundance $(p=0.032)$ and TdR incorporation ( $p=0.005$ ) over PME. PME+CNP had significantly lower bacterial abundance $(p=0.018)$, and higher TdR incor- 

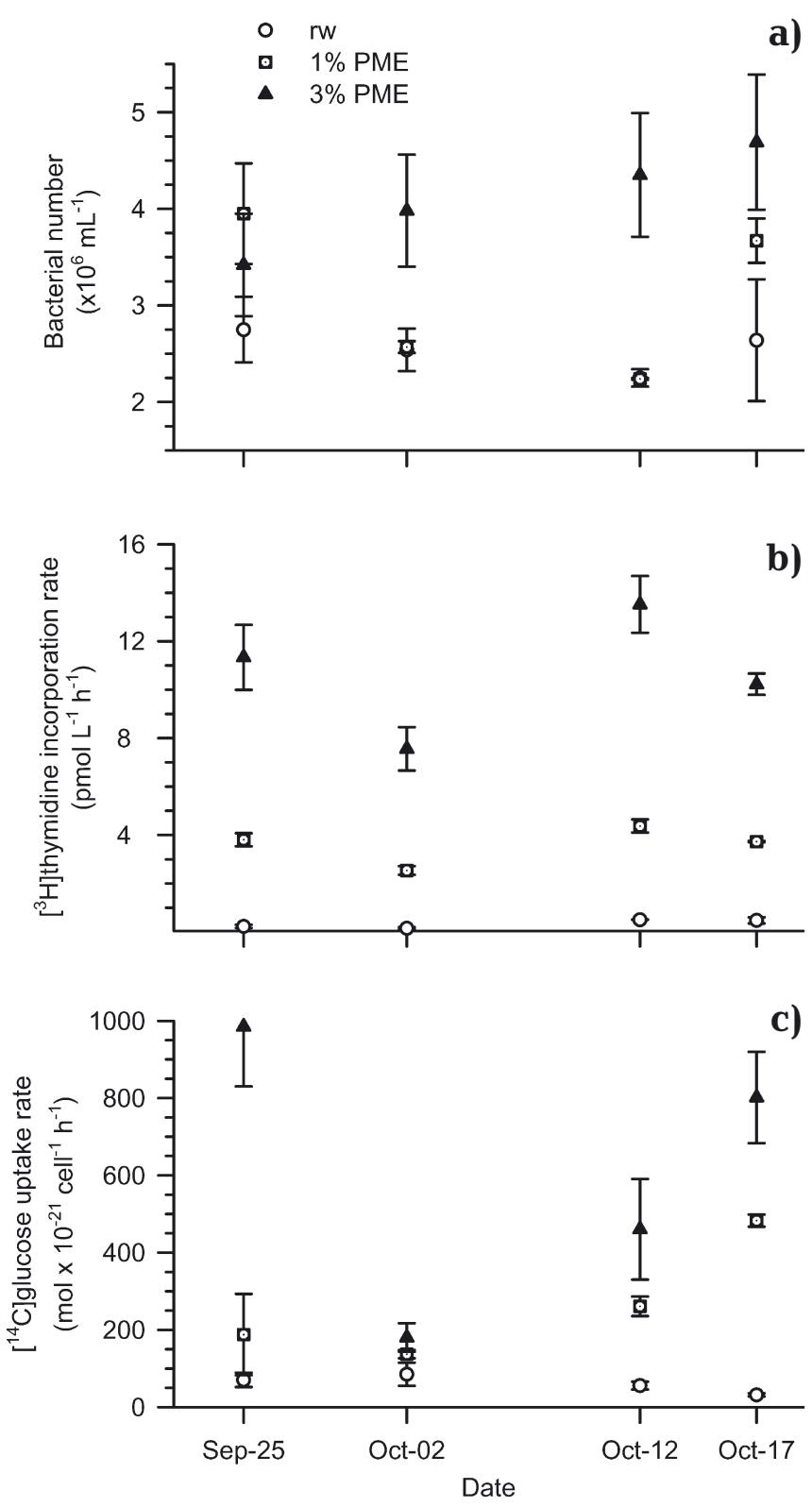

Fig. 1. (a) Bacterial abundance, (b) specific thymidine incorporation and (c) specific glucose uptake in mesocosms with unamended river water (rw), 1\% pulp-mill effluents (PME), and $3 \%$ PME. Error bars are SE of the mean

poration $(\mathrm{p}=0.001)$ compared to PME+NP. The apparent increase in glucose uptake was marginally nonsignificant $(\mathrm{p}=0.064)$.

In the spring experiment, as in autumn, PME addition produced higher bacterial abundance $(p=0.013)$, TdR incorporation ( $p=0.020)$, and glucose uptake $(p=0.002)$ compared to unamended river water (Fig. 3a). $\mathrm{PME}+\mathrm{C}$ showed no further increase in any measures over that in the PME treatment (bacterial abundance, $\mathrm{p}=0.311$; TdR incorporation, $\mathrm{p}=0.867$; glucose uptake, $\mathrm{p}=0.859$ ). $\mathrm{PME}+\mathrm{NP}$ resulted in significant increases in TdR incorporation $(\mathrm{p}<0.001)$ and glucose uptake $(\mathrm{p}$ $=0.003)$, but not in bacterial abundance $(p=0.612)$ over $\mathrm{PME}+\mathrm{C}$. PME+CNP was not higher in any of the measures over PME+NP (bacterial abundance, $p=0.676$; TdR incorporation, $p=0.098$; glucose uptake, $p=0.413$ ).

\section{Effluent activity experiment}

Volumetric glucose uptake in warm and cold raw effluent was approximately 660 and 400 times that of river water, respectively (data not shown). Bacterial abundance in the undiluted effluent was also far greater than in river water, with effluent containing approximately 26 times as many bacteria as river water $\left(2.4 \times 10^{9}\right.$ cells $1^{-1}$ in river water vs $63.4 \times$ $10^{9}$ cells $1^{-1}$ in effluent). Specific glucose uptake was ca. 15 times higher in the effluent $\left(\right.$ at $5^{\circ} \mathrm{C}$ ) than in river water $\left(76 \times 10^{-21} \mathrm{~mol} \mathrm{~h}^{-1}\right.$ cell $^{-1}$ in river water vs $1190 \times$ $10^{-21} \mathrm{~mol} \mathrm{~h}^{-1}$ cell $^{-1}$ in effluent).

\section{Sterile effluent experiment}

Addition of sterile-filtered PME to river water resulted in significant increases in bacterial abundance $(p=0.003)$, TdR incorporation $(p<0.001)$, and glucose uptake $(\mathrm{p}<0.001)$ over that of unamended river water (Fig. 3b). Addition of $\mathrm{C}$ to filtered PME-amended river water did not increase any parameters over the PMEF treatment (bacterial abundance, $\mathrm{p}=0.106$; TdR incorporation, $p=0.680$; glucose uptake, $p=0.751$ ). In contrast, TdR incorporation was greater in PMEF+NP than in $\mathrm{PMEF}+\mathrm{C}(\mathrm{p}=0.036)$, though glucose uptake was not $(p=0.378)$. None of the measures was greater in $\mathrm{PMEF}+\mathrm{CNP}$ than in $\mathrm{PMEF}+\mathrm{NP}$ (bacterial abundance, $\mathrm{p}=0.956$; TdR incorporation, $\mathrm{p}=0.570$; glucose uptake, $\mathrm{p}=0.601)$.

\section{Effluent versus sterile effluent response}

Bacterial response in the unfiltered PME was quite different over the course of the experiment than in PMEF (Fig. 3c). At 0 h, TdR incorporation and glucose uptake were higher in PME than unamended river water (TdR incorporation, $\mathrm{p}=0.014$; glucose uptake, $\mathrm{p}=0.002$ ), or in PMEF (TdR incorporation, $\mathrm{p}=0.01$; glucose uptake, $\mathrm{p}=0.001)$. Unamended river water and PMEF were not significantly different from each other in these parameters at $0 \mathrm{~h}$ (TdR incorporation, $\mathrm{p}=0.561$; glucose uptake, $\mathrm{p}=0.545$ ) .

In PME, TdR incorporation and glucose uptake dropped from over the course of the experiment. In 

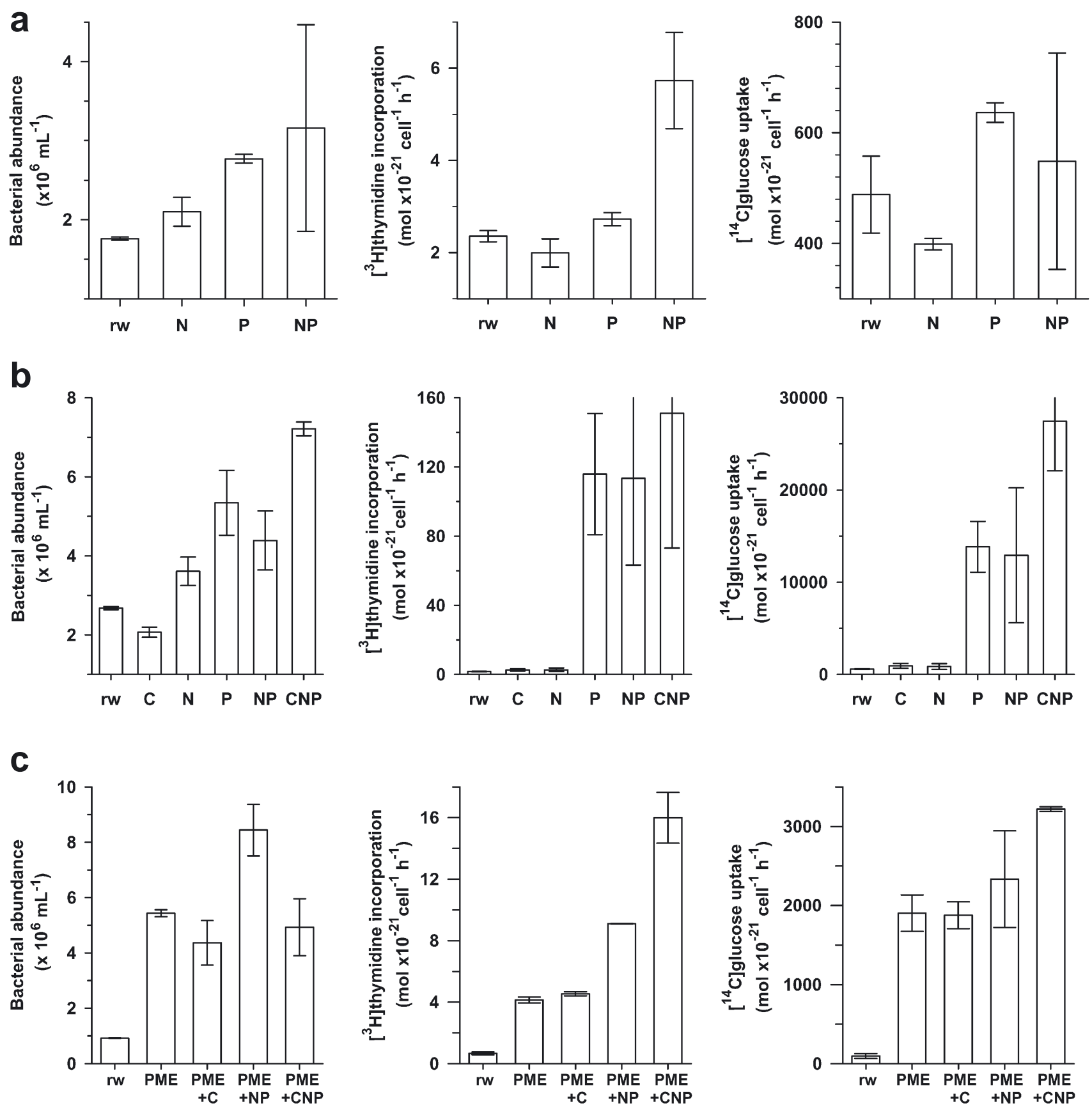

Fig. 2. Bacterial abundance, specific thymidine incorporation, and specific glucose uptake of the (a) autumn nutrient addition experiment, and (b) spring nutrient experiment, and (c) autumn pulp-mill effluent (PME)-nutrient interaction experiment. Treatments are: unamended river water $(\mathrm{rw})$, river water plus organic $\mathrm{C}(\mathrm{C})$, river water plus $\mathrm{N}(\mathrm{N})$, river water plus $\mathrm{P}(\mathrm{P})$, river water plus $\mathrm{N}$ and $\mathrm{P}(\mathrm{NP})$, and river water plus $\mathrm{C}, \mathrm{N}$, and $\mathrm{P}(\mathrm{CNP}), 3 \% \mathrm{PME}(\mathrm{PME}), 3 \% \mathrm{PME}$ plus organic $\mathrm{C}$ (PME+C), $3 \% \mathrm{PME}$ plus $\mathrm{N}$ and $\mathrm{P}(\mathrm{PME}+\mathrm{NP}), 3 \% \mathrm{PME}$ plus $\mathrm{C}, \mathrm{N}$, and $\mathrm{P}(\mathrm{PME}+\mathrm{CNP})$. Error bars are SE of the mean

PMEF, however, TdR incorporation and glucose uptake rose sharply after $102 \mathrm{~h}$. At $144 \mathrm{~h}$, TdR incorporation in PMEF was more than 4 times that of the PME treatment ( $p=0.009$ ), while glucose uptake in PMEF was more than twice that of the PME treatment $(\mathrm{p}=0.002)$.

\section{DISCUSSION}

\section{Nutrient addition experiments}

The autumn and spring nutrient experiments (Fig. 2a,b) showed that inorganic nutrients, mainly $\mathrm{P}$, 
a
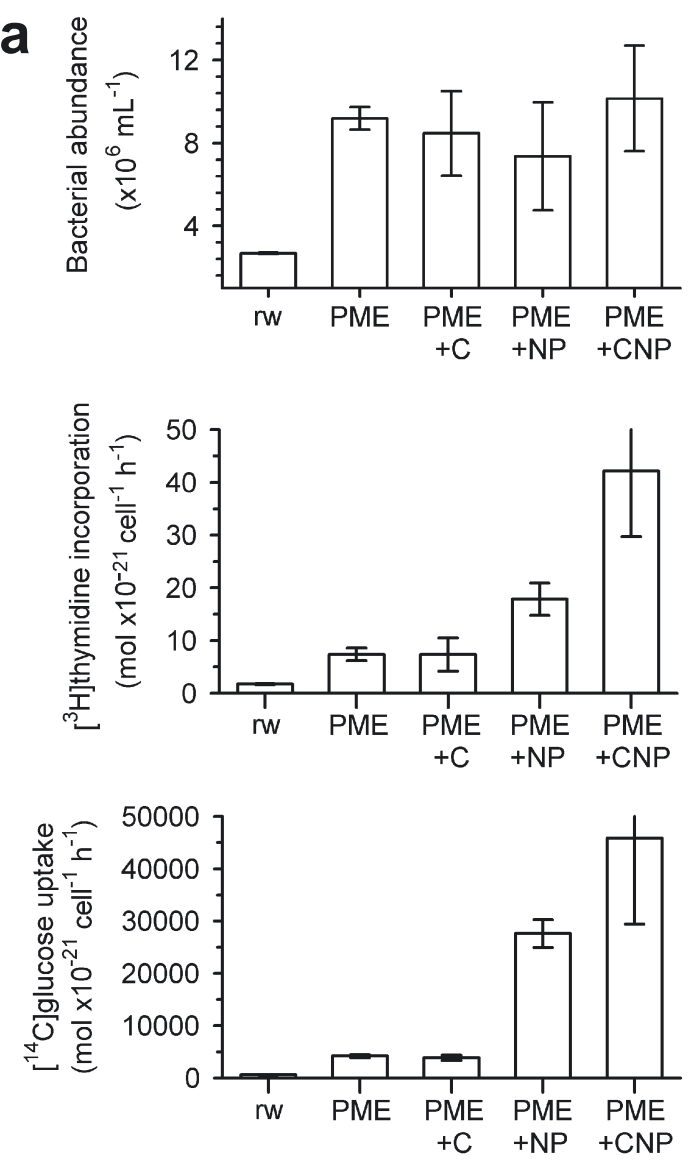

C

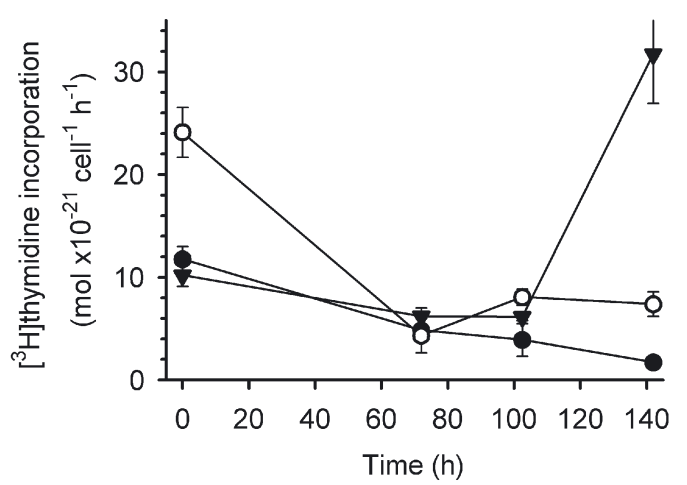

b
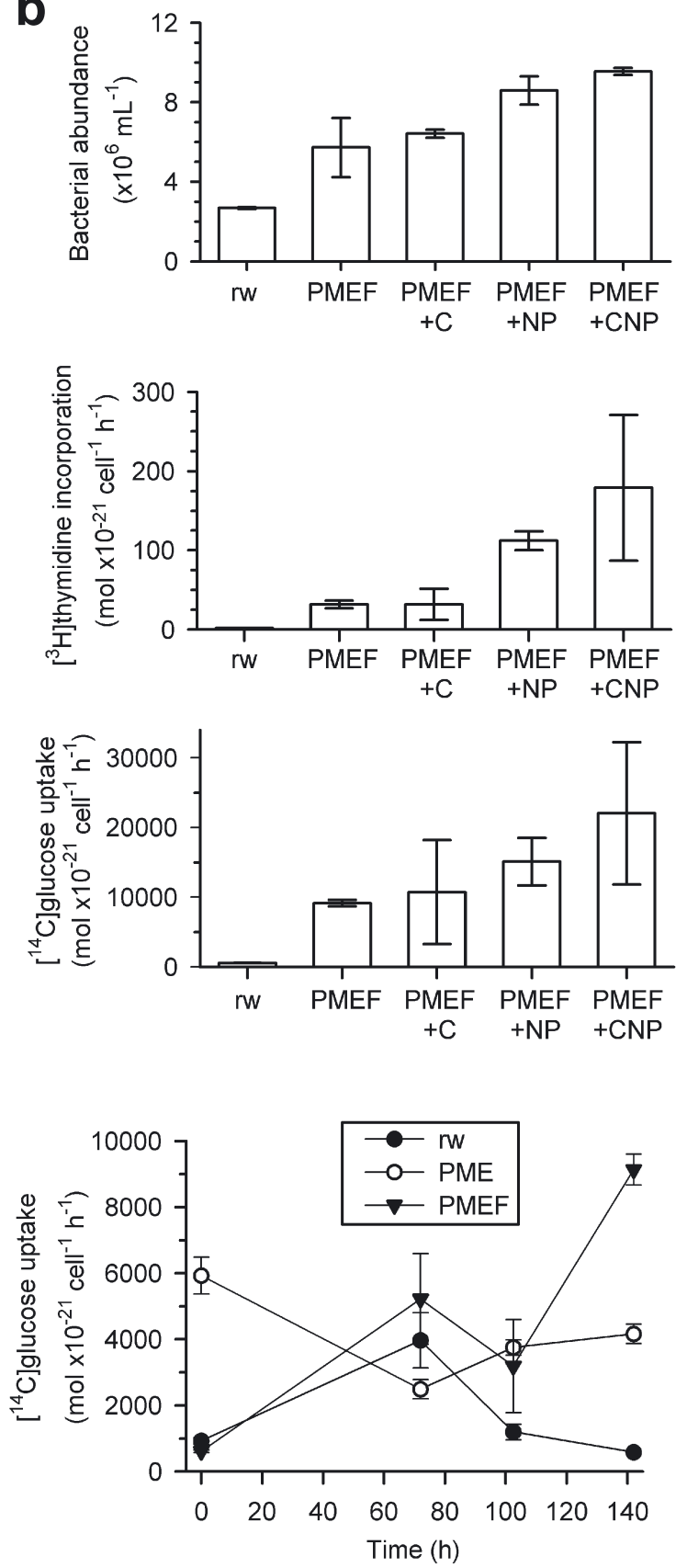

Fig. 3. Bacterial abundance, specific thymidine incorporation, and specific glucose uptake of the (a) spring pulp-mill effluent (PME)-nutrient interaction experiment, (b) sterile effluent experiment, and (c) comparison of 3\% unfiltered PME to $3 \%$ sterilefiltered PME. Treatments are: unamended river water (rw), $3 \%$ PME (PME), PME plus organic C (PME+C), PME plus N and $\mathrm{P}$ (PME+NP), PME plus C, N, and P (PME+CNP), filter-sterilised PME (PMEF), PMEF plus organic C (PMEF+C) PMEF plus N and P $(\mathrm{PMEF}+\mathrm{NP}), \mathrm{PMEF}$ plus $\mathrm{C}, \mathrm{N}$, and $\mathrm{P}(\mathrm{PMEF}+\mathrm{CNP})$. Error bars are SE of the mean

potentially limited bacterial growth in the Fraser River. In autumn, the increase in TdR incorporation with the addition of $\mathrm{N}$ and $\mathrm{P}$ together, but not with $\mathrm{P}$ alone, suggested that $\mathrm{N}$ was also important as a co-limiting factor for bacterial growth. In the spring experiment, $\mathrm{N}$ appeared to be less important, as $\mathrm{P}$ addition alone pro- duced dramatic increases in specific TdR incorporation and glucose uptake, while $\mathrm{N}$ addition alone did not result in an increase in these measures. Also, $\mathrm{N}$ and $\mathrm{P}$ added together did not result in any further increases compared to the P-added treatment in spring. Growth limitation of aquatic bacteria has been of interest to 
ecologists for a long time. Some studies have found C limitation of bacterial production in marine and fresh waters. Wang et al. (1992) provided evidence of bacterial C limitation in a eutrophic reservoir on some occasions, but limitation by inorganic nutrients on others. Kisand et al. (2001) found that bacteria in a eutrophic lake (Lake Võrtsjärv, Estonia) were limited by $\mathrm{C}$ supplied by phytoplankton. Organic C limitation of bacteria has also been observed in sub-Antarctic lakes (Robarts et al. 1991), and in the Southern Ocean (Church et al. 2000).

Other studies have found limitation of bacterial growth by inorganic nutrients. For example, P stimulated bacterial growth in an oligotrophic lake, while amino acids and glucose did not (Fahnenstiel et al. 1998). Chrzanowski et al. (1995) found that the addition of $\mathrm{P}$ alone stimulated bacterial growth in 2 oligotrophic lakes. Morris \& Lewis (1992) determined that bacterial production in a mesotrophic reservoir never increased with the addition of $\mathrm{C}$ (glucose and acetate) alone, but did increase with the addition of $\mathrm{P}$ alone, or P with C, or N. Jansson et al. (1996) demonstrated that bacteria in a humic lake were $\mathrm{P}$ limited for most of the ice-free season. P limitation of bacteria has also been found in coastal environments (Zweifel 1999), the open ocean (Rivkin \& Anderson 1997), and in saline prairie lakes (Waiser \& Robarts 1995).

Similarly, some studies have found bacterial growth in rivers to be limited by organic $\mathrm{C}$, while others have found it to be limited by inorganic nutrients. Previously, we showed that the growth of bacterial biofilm cultures from the Fraser River was increased with the addition of $\mathrm{P}$, but not with the addition of organic $\mathrm{C}$ or $\mathrm{N}$ (Mohamed et al. 1998). Bacterial growth was C limited at 2 sites on the main stem of the Amazon River, while there was a co-limitation between $\mathrm{C}$ and inorganic nutrients ( $\mathrm{N}$ and $\mathrm{P}$ ) on a blackwater tributary (Benner et al. 1995). Bacteria in the Maumee River, Ohio, were primarily C limited (Foreman et al. 1998). In a large oligotrophic river (the Skagit River, USA), bacterial growth was generally co-limited by $\mathrm{C}, \mathrm{N}$, and $\mathrm{P}$, with evidence of $\mathrm{P}$ limitation in some instances (Arthurs 1998).

We added nitrate rather than ammonium for $\mathrm{N}$ addition treatments. This was done, in part, to reduce the growth of nitrifying bacteria, as the effects of nutrients on the growth of heterotrophic bacteria were our focus. It is generally believed that approximately $70 \%$ of bacteria are incapable of using nitrate, while most heterotrophic bacteria can use ammonium as an $\mathrm{N}$ source (Neidhardt et al. 1990). The addition of nitrate rather than ammonium may, therefore, have reduced the effects of $\mathrm{N}$ additions compared to ammonium in our experiments.

For $\mathrm{C}$ additions, we used mixed amino acids, as they are available to a wide range of heterotrophic bacteria.
The amino acids may have also acted as a source of $\mathrm{N}$, so the $\mathrm{C}$ additions in the experiments should be viewed as $\mathrm{C}+\mathrm{N}$ additions. Since amino acid additions alone did not increase bacterial growth, this lends further support that $\mathrm{P}$ was limiting bacterial growth in the Fraser River.

As pointed out by Hecky \& Kilham (1988), enrichment experiments of the kind we used are not always conclusive. Long incubation times can result in bacterial growth on the walls of the flasks, reducing the concentration of $\mathrm{P}$ available to the seston during the experiments, and thereby enhancing the degree of $\mathrm{P}$ limitation in the seston. Sorption and desorption of $\mathrm{P}$ from particles could also cause $\mathrm{P}$ availability to differ in the incubation flasks compared to the river. Another possible problem was protozoan grazers of bacteria. No attempt to exclude protozoa was made, as small protozoa often pass through filters and would have had time to proliferate during the incubations. Their exclusion would have been partial, at best, and may have resulted in the introduction of other artefacts, such as nutrient release with cell breakage and exclusion of larger heterotrophic bacteria. Therefore, while our experimental approach was not able to definitively prove that $\mathrm{P}$ was limiting to bacteria in the Fraser River, it did demonstrate that it was potentially a key limiting factor, as the same experimental artefacts occurred in the control treatments. Indeed, the unequivocal proof of nutrient limitation in natural systems is not possible at this time with the experimental protocols available to aquatic microbial ecologists, which means, as with our approach, all these methods can only indicate a potential for limitation.

\section{PME addition experiments}

In the effluent addition experiments, the addition of $\mathrm{C}$ to PME did not stimulate bacterial abundance, production, or activity (Figs. 2c \& 3a). The addition of $\mathrm{N}$ and $\mathrm{P}$ to $\mathrm{PME}$, however, did increase bacterial abundance (autumn experiment), activity (spring experiment), and production (autumn and spring), showing that bacteria in $3 \%$ PME were limited by inorganic nutrients.

Addition of sterile-filtered PME caused an increase in all the bacterial parameters we measured, indicating that without the confounding effects of the highly active bacteria present in the effluent, PME could provide an essential nutrient for bacteria in the Fraser River (Fig. 3a). As the river water nutrient addition experiments showed that the limiting nutrient in the river was P (Fig. 2b,c), the PME likely acted as a source of labile P. The higher abundance and activity of bacteria in the effluent activity experiment compared to the river water confirmed that the effluent was also a source of active bacteria to the Fraser River (Fig. 3c). 
A comparison of the non-sterilised and filter-sterilised effluent additions demonstrated that riverine bacteria responded quite differently over the course of the experiment. While production rate and activity decreased in the non-filtered PME treatment, they increased in the filtered PME treatment. The likely reason for this difference is that highly active bacteria added in the unfiltered PME decreased in production and activity through time as they depleted the relatively low nutrient concentrations in the diluted PME. Conversely, the relatively inactive riverine bacteria in the filtered PME treatment would have increased their rates of production and metabolic activity in response to the relatively higher nutrient environment. While bacterial activity and production in the PME treatment decreased from their initial high rates, this does not necessarily make their addition to the river insignificant. PME would have increased bacterial abundance in the river by approximately 25 (at $1 \% \mathrm{PME}$ ) to $75 \%$ (at $3 \%$ PME) downstream of the effluent input. Allochthonous bacteria, whether active or not, may be an important food source for some river invertebrates (Edwards \& Meyer 1990). Additionally, C or nutrients released from these bacteria (either through consumption and excretion, or through cell lysis) could result in further bacterial or algal growth in the Fraser River.

No other studies have specifically considered the effects of PME on sestonic bacteria. Phosphorus in PME also stimulated the growth of biofilm bacteria from the Fraser River, as we have shown (Mohamed et al. 1998). In a study of the effect of PME on periphytic algae (Amblard et al. 1990) found an increase in 'heterotrophic activity' (measured as tritiated amino acid uptake) in periphyton exposed to PME. The authors ascribed these effects to algae in the periphyton switching to heterotrophic uptake of dissolved organic compounds. However, bacterial growth in the periphyton was likely important to the increase in heterotrophic biomass and activity, since autotrophic biomass (measured as chl a concentration) decreased relative to total biomass (measured as adenylate nucleotide concentration), while heterotrophic incorporation of amino acids increased relative to photosynthetic activity with the addition of PME.

In summary, we have shown that sestonic bacterial production in the Fraser River was potentially P limited. PME contributed both highly active bacteria and $\mathrm{P}$ to the riverine environment downstream of the mill effluent inflow. Thus, PME caused an increase in bacterial heterotrophic activity by concomitantly stimulating native bacterial production and introducing a large and highly active allochthonous bacterial population. The impact of similar combined effects on overall carbon flow and biological productivity in rivers needs further investigation.
Acknowledgements. The authors extend gratitude to Northwood Pulp and Timber for their cooperation and assistance. Thanks are due to J. M. Culp and K. J. Cash for providing the field research facility, access to unpublished data, and experimental design and statistical advice. The authors thank $\mathrm{M}$. J. Waiser for advice on the set-up of experimental procedures, V. Tumber for enumeration of bacterial samples, and J. Neary for help in the field. J. A. Wilson, W. D. Taylor and 3 anonymous reviewers provided improvements to the manuscript. This study was funded in part by the Fraser River Action Plan.

\section{LITERATURE CITED}

Amblard C, Couture P, Bourdier G (1990) Effects of a pulp and paper mill effluent on the structure and metabolism of periphytic algae in experimental streams. Aquat Toxicol 18:137-162

Anonymous (1991) Surface water data reference index Canada 1991. Minister of Supply and Services, Ottawa

Arthurs WJ (1998) Seasonal and spatial variation in phytoplankton and bacterioplankton biomass and production in the Skagit River, Washington. MSc thesis, Western Washington University, Bellingham

Azam F, Smith DC, Steward GF, Hagström Å (1994) Bacteriaorganic matter coupling and its significance for oceanic carbon cycling. Microb Ecol 28:167-179

Benner R, Opsahl S, Chin-Leo G, Richey JE, Forsberg BR (1995) Bacterial carbon metabolism in the Amazon River system. Limnol Oceanogr 40:1262-1270

Chrzanowski TH, Sterner RW, Elser JJ (1995) Nutrient enrichment and nutrient regeneration stimulation bacterioplankton growth. Microb Ecol 29:221-230

Church MJ, Hutchins DA, Ducklow HW (2000) Limitation of bacterial growth by dissolved organic matter and iron in the Southern Ocean. Appl Environ Microbiol 66:455-466

Culp JM, Podemski CL, Cash KJ, Lowell RB (1996) Utility of field-based artificial streams for assessing effluent effects on riverine ecosystems. J Aquat Ecosyst Health 5: $117-124$

Edwards RT, Meyer JL (1990) Bacterivory by deposit-feeding mayfly larvae (Stenonema spp.). Freshw Biol 24:453-462

Fahnenstiel GL, Krause AE, McCormick MJ, Carrick HJ, Schelske CL (1998) The structure of the planktonic foodweb in the St. Lawrence Great Lakes. J Gt Lakes Res 24: $531-554$

Foreman CM, Franchini P, Sinsabaugh RL (1998) The trophic dynamics of riverine bacterioplankton: relationships among substrate availability, ectoenzyme kinetics, and growth. Limnol Oceanogr 43:1344-1352

Gibbons JS, Kovacs TG, Voss RH, O'Connor BI, Dorcia JG (1992) An appraisal of the effect of biological treatment on the environmental quality of high-yield mechanical pulping effluents. Water Res 11:1425-1432

Hecky RE, Kilham P (1988) Nutrient limitation of phytoplankton in fresh-water and marine environments - a review of recent-evidence on the effects of enrichment. Limnol Oceanogr 33:796-822

Jansson M, Blomqvist P, Jonsson A, Bergstrom AK (1996) Nutrient limitation of bacterioplankton, autotrophic and mixotrophic phytoplankton, and heterotrophic nanoflagellates in Lake Ortrasket. Limnol Oceanogr 41: 1552-1559

Kisand V, Tuvikene L, Noges T (2001) Role of phosphorus and nitrogen for bacteria and phytoplankton development in a large shallow lake. Hydrobiologia 457:187-197

McLeay DJ (1987) Aquatic toxicology of pulp and paper mill 
effluent: a review. Report 4/PF/1. Environment Canada, Ottawa

Meyer JL (1994) The microbial loop in flowing waters. Microb Ecol 28:195-199

Mohamed MN, Lawrence JR, Robarts RD (1998) Phosphorus limitation of biofilm bacteria in the Fraser River and the effect of pulp mill effluent. Microb Ecol 36:121-130

Morris DP, Lewis WM Jr (1992) Nutrient limitation of bacterioplankton growth in Lake Dillon, Colorado. Limnol Oceanogr 37:1179-1192

Neidhardt FC, Ingraham JL, Schaechter M (1990) Physiology of the bacterial cell: a molecular approach. Sinauer Associates, Sunderland, MA

Paul BJ, Duthie HC, Taylor WD (1991) Nutrient cycling by biofilms in running waters of different nutrient status. J N Am Benthol Soc 10:31-41

Rivkin RB, Anderson MR (1997) Inorganic nutrient limitation of oceanic bacterioplankton. Limnol Oceanogr 42:730-740

Robarts RD, Wicks RJ (1989) [Methyl- ${ }^{3} \mathrm{H}$ ]thymidine macromolecular incorporation and lipid labeling: their significance to DNA labeling during measurements of bacterial growth rate. Limnol Oceanogr 34:213-222

Robarts RD, Zohary T (1993) Fact or fiction-bacterial growth rates and production as determined by [methyl- ${ }^{3} \mathrm{H}$ ] thymidine? Adv Microb Ecol 13:371-475

Robarts RD, Sephton LM, Wicks RJ (1991) Labile dissolved organic carbon and water temperature as regulators of het-

Editorial responsibility: Frede Thingstad,

Bergen, Norway erotrophic bacterial activity and production in the lakes of Sub-Antarctic Marion Island. Polar Biol 11:403-413

Swain LG, Walton DG, Obedkof W (1994) Water quality assessment and objectives, Fraser River from Moose Lake to Hope. Science Division, Environmental Conservation Branch, Pacific and Yukon region, Environment Canada, Ottawa

Velji MI, Albright LJ (1993) Improved sample preparation for enumeration of aggregated aquatic substrate bacteria. In: Kemp PF, Sherr BF, Sherr EB, Cole JJ (eds) Handbook of methods in aquatic microbial ecology. Lewis Publishers, Boca Raton, FL, p 139-142

Wainwright SC, Couch CA, Meyer JL (1992) Fluxes of bacteria and organic matter into a Blackwater River from river sediments and floodplain soils. Freshw Biol 28:37-48

Waiser MJ, Robarts RD (1995) Microbial nutrient limitation in prairie saline lakes with high sulfate concentration. Limnol Oceanogr 40:574-566

Wang L, Miller TD, Priscu JC (1992) Bacterioplankton nutrient deficiency in a eutrophic lake. Arch Hydrobiol 125: 423-439

Wright RT, Coffin RB (1984) Measuring microzooplankton grazing on planktonic marine bacteria by its impact on bacterial production. Microb Ecol 10:137-149

Zweifel UL (1999) Factors controlling accumulation of labile dissolved organic carbon in the Gulf of Riga. Estuar Coast Shelf Sci 48:357-370

Submitted: January 27, 2003; Accepted: June 20, 2003

Proofs received from author(s): August 7, 2003 